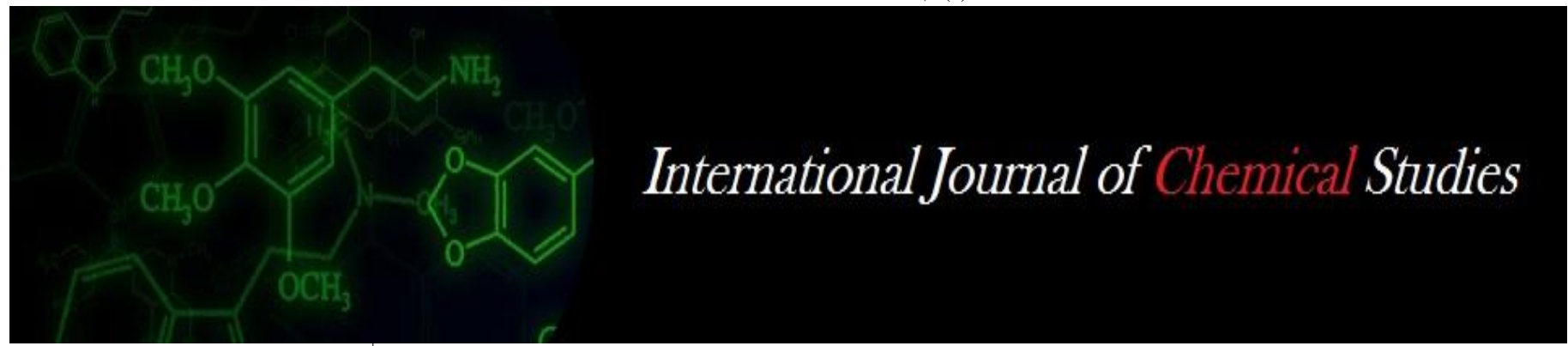

P-ISSN: 2349-8528

E-ISSN: 2321-4902

www.chemijournal.com

IJCS 2020; 8(6): 619-626

(C) 2020 IJCS

Received: 10-09-2020

Accepted: 17-10-2020

\section{Jayanta Das}

Department of Soil Science and

Agricultural Chemistry, Post

Graduate Institute, Akola, DR.

Panjabrao Deshmukh Krishi

Vidyapeeth, Krishnagar PO,

Akola, Maharashtra, India

\section{Arati S Ghatole}

Department of Soil Science and Agricultural Chemistry, Post Graduate Institute, Akola, DR. Panjabrao Deshmukh Krishi Vidyapeeth, Krishnagar PO, Akola, Maharashtra, India

Jyoti Sharad Shirankar Department of Soil Science and Agricultural Chemistry, Post Graduate Institute, Akola, DR. Panjabrao Deshmukh Krishi Vidyapeeth, Krishnagar PO,

Akola, Maharashtra, India

\section{NM Konde}

Department of Soil Science and Agricultural Chemistry, Post Graduate Institute, Akola, DR. Panjabrao Deshmukh Krishi Vidyapeeth, Krishnagar PO, Akola, Maharashtra, India

Corresponding Author: Jayanta Das

Department of Soil Science and Agricultural Chemistry, Post Graduate Institute, Akola, DR. Panjabrao Deshmukh Krishi Vidyapeeth, Krishnagar PO, Akola, Maharashtra, India

\section{Effect of continuous adoption of conservation agriculture management practices on soil chemical properties under soybean in Vertisol}

\author{
Jayanta Das, Arati S Ghatole, Jyoti Sharad Shirankar and NM Konde
}

DOI: https://doi.org/10.22271/chemi.2020.v8.i6i.10841

\begin{abstract}
A field experiment was conducted during kharif 2018/19 on farmer's field in three villages of Barshi takali tehsil under Department of Soil Science and Agricultural Chemistry, Dr. PDKV, Akola (MS). The experiment consisted of ten treatments in randomized block design replicated thrice were each farmer has been treated as single treatment and each sample taken from a treatments has been treated as one replication. The soil of experimental site was Vertisol belonging to fine, smectitic, hyperthermic, Typic Haplusterts. It was calcareous in nature and moderately alkaline in reaction. The fertility status of the soil indicates that the soil was moderate in organic carbon, available nitrogen and phosphorus and very high in available potassium. Result revealed that the lower value of $\mathrm{pH}$ (7.77), higher value of EC ( $0.35 \mathrm{dS} \mathrm{m}^{-}$ $\left.{ }^{1}\right)$, highest value of organic carbon content $\left(7.80 \mathrm{~g} \mathrm{~kg}^{-1}\right)$, and lowest value of calcium carbonate content $(7.63 \%)$ was recorded in $\mathrm{T}_{1}$ where, conservation agriculture management practices were followed since last 15 years. The highest value of available nitrogen $\left(225.38 \mathrm{~kg} \mathrm{ha}^{-1}\right)$, available phosphorus $(23.81 \mathrm{~kg} \mathrm{ha}$ $\left.{ }^{1}\right)$, available potassium $\left(419.70 \mathrm{~kg} \mathrm{ha}^{-1}\right)$ and available sulphur $\left(12.00 \mathrm{~kg} \mathrm{ha}^{-1}\right)$ were recorded in $\mathrm{T}_{1}$ where, conservation agriculture management practices were followed since last 15 years.
\end{abstract}

Keywords: Conservation agriculture, chemical properties, organic carbon, Vertisols

\section{Introduction}

Ever-increasing global population, particularly in many developing countries requires increased supply of food, fiber, oil, which poses a grave challenge before the agricultural scientists to produce more and more from limited, shrinking, degraded land and water resources. Tilling soils continuously without adding organic matter has adverse effects on soil health and quality of produce. India alone needs to produce additional 64 million tonnes of food over the next decade to achieve targeted 294 million tonnes by 2020. Soil C and N sequestration need to be enhanced to sustain the resources, ensuring that earlier production grains are sustained and possibly further enhanced to meet the emerging needs. The concerns for erosion, soil-quality deterioration, and chemical hazards loom large in recent years and have compelled the scientists/researchers to look back to the past towards evolving conservation agriculture based systems/practices, which aim at higher productivity and profitability through rational and sustainable use of available resources on a long-term basis. Conservation agriculture, emphasizing the minimum soil disturbance, permanent soil cover through crop residues or other cover crops and diversified crop rotation using a legume, is a promising technology for rational use of available resources and sustainable productivity in the long-run. Conservation agriculture reverses soil degradation processes and builds up soil fertility through increase in water holding capacity and facilitating better infiltration of rainwater and enhancing groundwater storage, enrichment in soil organic carbon (SOC), and enhanced microbial diversity in the rhizosphere. It eliminates power-intensive soil tillage, thus reducing the drudgery and labor required for crop production by more $50 \%$ of the small-scale farmers. Conservation agriculture has a long-term and broader perspective, which goes beyond yield improvement.

\section{Material and Methods}

The field experiment was conducted on farmer's field in three villages viz., Sukali, Alanda and Nimbhara under Barshi takali tehsil. 
All the farmers have been following no tillage practices for last few years except one farmer who have been regularly following conventional agricultural practices. All the farmers have been following same cropping pattern for last ten years. Soybean and pigeon pea intercrop was grown in kharif seoson and in summer chickpea was grown for last ten years. The present investigation was conducted in kharif 2018-19 with soybean as a test crop. The initial soil sample have been collected from every farmes and analyzed the various soil properties.

Table 1: Experimental details

\begin{tabular}{|c|c|c|c|c|}
\hline \multirow{3}{*}{ Sr. No } & \multirow{3}{*}{ Site } & \multirow{3}{*}{ Treatment } & \multicolumn{2}{|c|}{ Cropping Pattern } \\
\hline & & & 2018-19 & Menorament Droctices \\
\hline & & & Kharif & Management Practices \\
\hline 1 & $\begin{array}{c}\text { Site } 1 \\
\text { (Yogesh Hage) }\end{array}$ & $\mathrm{T}_{1}$ & -Soybean + Pigeon pea & $\begin{array}{l}\text {-No ploughing since } 15 \text { years } \\
\text { - Harrowing } \\
\text {-Crop residues incorporated in soil }\end{array}$ \\
\hline 2 & $\begin{array}{c}\text { Site } 2 \\
\text { (Babulal Charawane) }\end{array}$ & $\mathrm{T}_{2}$ & -Soybean + Pigeon pea & $\begin{array}{l}\text { - No ploughing since } 8 \text { years } \\
\text {-Harrowing } \\
\text {-Crop residues incorporated in soil }\end{array}$ \\
\hline 3 & $\begin{array}{c}\text { Site } 3 \\
\text { (Sakari Yawatkar) }\end{array}$ & $\mathrm{T}_{3}$ & -Soybean + Pigeon pea & $\begin{array}{l}\text {-No ploughing since 4years } \\
\text {-Harrowing } \\
\text {-Crop residues incorporated in soil }\end{array}$ \\
\hline 4 & $\begin{array}{c}\text { Site } 4 \\
\text { (Purshottam Lande) }\end{array}$ & $\mathrm{T}_{4}$ & -Soybean + Pigeon pea & -Regular ploughing each year \\
\hline 5 & $\begin{array}{c}\text { Site } 5 \\
\text { (Ramdas Kakad) }\end{array}$ & $\mathrm{T}_{5}$ & -Soybean + Pigeon pea & $\begin{array}{l}\text {-No ploughing since } 12 \text { years } \\
\text {-Harrowing } \\
\text {-Crop residues incorporated in soil }\end{array}$ \\
\hline 6 & $\begin{array}{c}\text { Site } 6 \\
\text { (Sanjay Bhawane) }\end{array}$ & $\mathrm{T}_{6}$ & -Soybean + Pigeon pea & $\begin{array}{l}\text {-No ploughing since } 10 \text { years } \\
\text {-Harrowing } \\
\text {-Crop residues incorporated in soil }\end{array}$ \\
\hline 7 & $\begin{array}{c}\text { Site } 7 \\
\text { (Ramrao Wannere) }\end{array}$ & $\mathrm{T}_{7}$ & -Soybean + Pigeon pea & $\begin{array}{c}\text {-No ploughing since } 6 \text { years } \\
\text {-Harrowing } \\
\text {-Crop residues incorporated in soil }\end{array}$ \\
\hline 8 & $\begin{array}{c}\text { Site } 8 \\
\text { (Sanjay Dhore) } \\
\end{array}$ & $\mathrm{T}_{8}$ & -Soybean + Pigeon pea & $\begin{array}{l}\text { - No ploughing since } 1 \text { year } \\
\text { - Crop residues incorporated in soil }\end{array}$ \\
\hline 9 & $\begin{array}{c}\text { Site } 9 \\
\text { (Ganesh Nanote) }\end{array}$ & $\mathrm{T}_{9}$ & -Soybean + Pigeon pea & $\begin{array}{c}\text { - No ploughing since } 3 \text { year } \\
\text { - Crop residues incorporated in soil }\end{array}$ \\
\hline 10 & $\begin{array}{c}\text { Site } 10 \\
\text { (Najakrao Nanote) }\end{array}$ & $\mathrm{T}_{10}$ & -Soybean + Pigeon pea & $\begin{array}{l}\text { - No ploughing since } 2 \text { year } \\
\text { - Crop residues incorporated in soil }\end{array}$ \\
\hline
\end{tabular}

Each sample has been treated as one replication and three samples have been taken from each site. Thus 10 treatments with 3 replications has been studied using RBD design.

\section{Location, duration and season of experiment}

The experiment on "Effect of continuous adoption of conservation agriculture management practices on soil health in Vertisol" carried out on the Farmers field of Barshi takali tehsil, Akola during kharif 2018-19.

\section{Climate and weather conditions}

Akola is situated in sub-tropical region between $22^{0} 42^{\prime} \mathrm{N}$ latitude and $77^{\circ} 02^{\prime} \mathrm{E}$ longitudes. The altitude of the place is $304.42 \mathrm{~m}$ above mean sea level. The climate of Akola is semiarid and characterized by three distinct season viz., hot and dry summer from March to May, warm humid rainy season from June to October and mild cold winter from November to February. Average annual precipitation on the basis of last fifteen years is $515.8 \mathrm{~mm}$. Monthly weather data recorded at Agro-meteorology Observatory, Dr. PDKV, Akola during 2018-19 along with corresponding normal are presented in Table 1. Weather situation during 2018-19 and the crop season has been described briefly in following sections.

\section{Rainfall}

Month wise rainfall distribution at Akola during June 2018 to March 2019 is presented in Table 1. The month wise data along with normal on various other weather parameters recorded at Agro-meteorology Observatory, Dr. PDKV, Akola during 2018-19 is also presented in Table 1. Rainfall during Kharif 2018 (June- September) amounted $830.1 \mathrm{~mm}$ which was $127 \%$ of the corresponding normal rainfall (656.2 $\mathrm{mm})$. Monthly rainfall during June, July, August and September amounted to 291.6, 261.9, 212.2 and $64.4 \mathrm{~mm}$ which was 104, 130, 112 and 52 per cent of the monthly normal (1981-2010), respectively. During post monsoon period (October- December) rain events recorded were during 20 November amounting to $4.5 \mathrm{~mm}$. Remaining post monsoon months (November to December) and winter months (January and February) did not receive any rain day event affecting rainfed rabi crops. Further rainless weather continued across March month also. Total rainy days during June to September were 41 as against the normal of 34 days.

\section{Air Temperature}

The average maximum high temperature of $43.7{ }^{\circ} \mathrm{C}$ was recorded in May 2018 while, average minimum low temperature of $10.5{ }^{\circ} \mathrm{C}$ was recorded in Janury 2019. By and large, the temperature deviation showed mostly above normal trend with very few occasions below normal deviation across the season, which affected growth and development of soybean crop.

\section{Relative Humidity}

The higher relative humidity of $88 \%$ was observed in July 2018 and the lower relative humidity of $33 \%$ was observed in April 2018. Higher humidity range across most part of the monsoon season was due to rainy/cloudy monsoon atmosphere. Overall actual evening relative humidity more or less followed the trend of morning relative humidity. 


\section{Pan Evaporation}

The higher pan evaporation of $14.9 \mathrm{~mm}$ was recorded in May 2018 while, the lower pan evaporation of $4.3 \mathrm{~mm}$ was recorded in December 2018.

\section{Bright sunshine hours}

The higher bright sunshine of $9.1 \mathrm{hrs}$ was recorded in April 2018 while, lower bright sunshine of $2.0 \mathrm{hrs}$ was recorded in July and August 2018.

During the major part of post-monsoon and winter months BSH values were above normal (+0.6 to $+1.2 \mathrm{hrs})$, excepting marginally below normal values during $45 \mathrm{MW}$ (1.2 hrs). By and large, lower than normal bright sunshine hours might have interfered with the potential photosynthetic activity of crop plants. Also it might have facilitated availability of soil moisture for comparatively longer period of time.

\section{Wind speed}

Wind speed was lower than normal through- out the kharif as well as rabi growing season. Except during $26 \mathrm{MW}(+2.2$ $\mathrm{km} / \mathrm{hr}$ ) of monsoon phase, It remained markedly lower than normal across the kharif as well as rabi growing season. Lower wind speed keeps the rate of evaporation lower benefiting kharif and rabi crops.

\section{Soil}

The soil of experimental site was Vertisol belonging to fine, smectitic, hyperthermic, Typic Haplusterts. It was calcareous in nature and moderately alkaline in reaction. The fertility status of the soil indicates that the soil was moderate in organic carbon, available nitrogen and phosphorus and very high in available potassium.

\section{Cropping history of the experimental plot}

The field experiment was conducted on farmer's field in three villages of Barshi takali tehsil. All the farmers have been following no tillage practices for last few years except one farmer who have been regularly following conventional agricultural practices. All the farmers have been following same cropping pattern for last ten years. Soybean and pigeon pea intercrop was grown in kharif seoson and in summer chickpea was grown for last ten years. The present investigation was conducted in kharif 2018-19 with soybean as a test crop. The initial soil sample have been collected from every farmer and analyzed the various soil properties.

\section{Statistical analysis}

Experimental data were analysed by adopting standard statistical methods of analysis of variance as given by Gomez and Gomez (1984). The field experiment was conducted in Farmer's field of three villages viz., Sukali, Alanda and Nimbhara under Barshi takali tehsil. The performances of ten treatments on different conservation management practices were separately analysed by using RBD.

\section{Methods adopted}

\section{Collection and processing of soil samples}

The treatment wise initial surface soil samples $(0-20 \mathrm{~cm})$ before sowing in kharif (2018-19) from experimental site and after harvest of kharif were collected. Soil samples were air dried in shade and stored in polythene bags for further analysis. The air dried samples were carefully and gently ground with the wooden pestle to break soil lumps (clods) and passed through sieve of $2 \mathrm{~mm}$ diameter. The sieved samples were mixed thoroughly and stored in polythene bags, properly labelled and preserved for subsequent analysis. Soil samples for biological parameters was collected during peak growth stages or grand growth stages of crop and immediately analysed.

\section{Soil analysis}

Soil chemical properties

Soil reaction $(\mathbf{p H})$

Hydrogen ion activity expressed as $\mathrm{pH}$ was measured with $\mathrm{pH}$ meter using 1:2.5 soil-water suspension (Jackson, 1973) ${ }^{[11]}$.

\section{Electrical conductivity}

The clear supernatant extract obtained from soil-water suspension used for $\mathrm{pH}$ was utilized for the EC measurement using a conductivity bridge (Jackson, 1973) ${ }^{[11]}$.

\section{Organic carbon}

Walkley and Black method as described by Jackson, $1973^{[11]}$ was used to determine organic carbon content of soil.

\section{Calcium carbonate content $\left(\mathrm{CaCO}_{3}\right)$}

Rapid titration method as directed by Piper (1966) ${ }^{[20]}$ was used to determine the calcium carbonate content of soil.

\section{Available nutrients Nitrogen}

Available nitrogen was determined by alkaline permanganate method using microprocessor based automatic distillation system (Subbiah and Asija, 1956) ${ }^{[26] .}$

\section{Phosphorus}

Available phosphorus was determined by Olsen's method using $0.5 \mathrm{M}$ sodium bi-carbonate as an extractant using UV based double beam spectrophotometer (Watanabe and Olsen, 1965) ${ }^{[28]}$.

\section{Potassium}

Available potassium was determined by neutral normal ammonium acetate method using flame photometer (Knudsen and Peterson, 1982) ${ }^{[15]}$.

\section{Available Sulphur}

Available sulphur was determined by Morgan's reagent as extractant (Turbidimetric method) using UV based double beam spectrophotometer (Chesnin and Yien, 1950) ${ }^{[4]}$.

\section{Yield of soybean}

Yield of soybean was picked from net plots in all the replications and yield per plot and yield per hectare was calculated.

Table 2: Monthly Weather data for the year 2018-2019 recorded at Meteorological Observatory, Department of Agronomy, Dr PDKV., Akola

\begin{tabular}{|c|c|c|c|c|c|c|c|c|c|c|c|c|c|c|c|c|c|c|c|}
\hline \multicolumn{20}{|c|}{ Actual 2018-19 Normal 1981-2010 } \\
\hline Month & T MA & $\left({ }^{\circ} \mathrm{C}\right)$ & T MI & $\left({ }^{\circ} \mathrm{C}\right)$ & BSF & (hrs) & Ws ( & n/hr) & RHI & $(\%)$ & RH & $(\%)$ & Evap & mm) & RF ( & nm) & CRF & mm) & Rainy Days \\
\hline 2018 & $\mathbf{N}$ & A & $\mathbf{N}$ & $\mathbf{A}$ & $\mathbf{N}$ & $\mathbf{A}$ & $\mathbf{N}$ & $\mathbf{A}$ & $\mathbf{N}$ & A & $\mathbf{N}$ & A & $\mathbf{N}$ & $\mathbf{A}$ & $\mathbf{N}$ & $\mathbf{A}$ & & $\mathbf{N}$ & $\mathbf{A}$ \\
\hline January & 29.8 & 30.2 & 11.8 & 10.9 & 8.2 & 7.9 & 4.2 & 1.2 & 70 & 63 & 29 & 21 & 4.4 & 5.8 & 10.7 & 0.0 & 0.0 & 0.9 & 0 \\
\hline February & 32.6 & 33.1 & 13.7 & 15.8 & 8.8 & 7.1 & 4.9 & 2.2 & 57 & 55 & 22 & 22 & 6.3 & 7.2 & 7.4 & 0.7 & 0.7 & 0.6 & 0 \\
\hline
\end{tabular}




\begin{tabular}{|c|c|c|c|c|c|c|c|c|c|c|c|c|c|c|c|c|c|c|c|}
\hline March & 37.0 & 37.4 & 18.2 & 20.3 & 8.9 & 7.2 & 6.0 & 3.0 & 45 & 38 & 18 & 15 & 9.1 & 9.0 & 15.2 & 3.4 & 4.1 & 1.1 & 1 \\
\hline April & 41.0 & 41.8 & 23.5 & 25.4 & 9.4 & 9.1 & 8.0 & 3.9 & 38 & 33 & 15 & 12 & 12.7 & 11.7 & 2.6 & 0.3 & 4.4 & 0.4 & 0 \\
\hline May & 42.3 & 43.7 & 27.5 & 30.3 & 9.4 & 8.6 & 12.8 & 7.5 & 46 & 37 & 19 & 15 & 15.6 & 14.9 & 12.4 & 0.5 & 4.9 & 1.2 & 0 \\
\hline June & 37.5 & 36.6 & 25.9 & 25.2 & 6.7 & 5.4 & 13.5 & 11.2 & 69 & 74 & 41 & 43 & 10.7 & 9.8 & 142.6 & 291.6 & 296.5 & 6.8 & 13 \\
\hline July & 32.1 & 30.0 & 23.9 & 23.9 & 4.0 & 2.0 & 10.6 & 6.4 & 83 & 88 & 61 & 70 & 5.3 & 4.4 & 200.7 & 261.9 & 558.4 & 10.8 & 18 \\
\hline August & 30.4 & 29.6 & 23.1 & 23.7 & 3.7 & 2.0 & 9.9 & 8.5 & 87 & 86 & 68 & 69 & 4.1 & 4.5 & 189.7 & 212.2 & 770.6 & 9.9 & 8 \\
\hline September & 32.1 & 32.1 & 22.5 & 23.0 & 6.0 & 5.9 & 6.8 & 3.9 & 85 & 84 & 57 & 52 & 4.6 & 4.7 & 123.2 & 64.4 & 835.0 & 6.5 & 2 \\
\hline October & 33.4 & 35.0 & 18.6 & 18.8 & 7.9 & 8.7 & 3.7 & 0.7 & 78 & 73 & 39 & 30 & 4.9 & 5.2 & 53.9 & 0.0 & 835.0 & 2.9 & 0 \\
\hline November & 31.5 & 33.2 & 14.2 & 16.4 & 8.2 & 8.1 & 3.4 & 0.6 & 72 & 73 & 32 & 29 & 4.5 & 4.8 & 18.8 & 4.5 & 839.5 & 1.1 & 1 \\
\hline December & 29.6 & 28.5 & 11.1 & 12.0 & 8.1 & 7.0 & 3.4 & 1.1 & 71 & 73 & 29 & 33 & 4.0 & 4.3 & 11.5 & 0.0 & 839.5 & 1.6 & 0 \\
\hline 2019 & & & & & & & & & & & & & & & & & & & \\
\hline January & 29.8 & 28.4 & 11.8 & 10.5 & 8.2 & 7.6 & 4.2 & 1.2 & 70 & 69 & 29 & 27 & 4.4 & 4.9 & 10.7 & 0.0 & 0.0 & 0.9 & 0.0 \\
\hline February & 32.6 & 32.2 & 13.7 & 15.6 & 8.8 & 8.2 & 4.9 & 3.0 & 57 & 53 & 22 & 22 & 6.3 & 6.4 & 7.4 & 1.9 & 1.9 & 0.6 & 0.0 \\
\hline March & 37.0 & 36.7 & 18.2 & 16.9 & 8.9 & 8.9 & 6.0 & 2.6 & 45 & 44 & 18 & 20 & 9.1 & 7.9 & 15.2 & 0.0 & 1.9 & 1.1 & 0.0 \\
\hline
\end{tabular}

Table 3: Initial physical and chemical properties of soil

\begin{tabular}{|c|c|c|c|c|c|c|c|c|c|c|c|c|}
\hline \multirow{3}{*}{ Treatments } & \multicolumn{4}{|c|}{ Physical properties of soil } & \multicolumn{8}{|c|}{ Chemical properties of soil } \\
\hline & \multirow{2}{*}{\begin{tabular}{|c|}
$\mathbf{B D}$ \\
$\left(\mathbf{M g ~ m}^{-3}\right)$ \\
\end{tabular}} & \multirow{2}{*}{\multicolumn{2}{|c|}{\begin{tabular}{|l|c|}
$\mathbf{M W D}$ & $\mathbf{H C}$ \\
$(\mathbf{m m})$ & $\left(\mathbf{c m ~ h}^{-1}\right)$ \\
\end{tabular}}} & \multirow{3}{*}{\begin{tabular}{|c|}
$\begin{array}{c}\text { Soil moisture } \\
(\mathbf{\%})\end{array}$ \\
13.07 \\
\end{tabular}} & \multirow{3}{*}{\begin{tabular}{|c|}
$\mathbf{p H}$ \\
$(\mathbf{1 : 2 . 5})$ \\
7.95 \\
\end{tabular}} & \multirow{2}{*}{$\begin{array}{c}\mathbf{E C} \\
\left(\mathbf{d} \mathbf{S} \mathbf{~ m}^{-1}\right)\end{array}$} & \multirow{2}{*}{\begin{tabular}{|c|}
$\mathbf{O C}$ \\
$\left(\mathrm{g} \mathrm{kg}^{-1}\right)$ \\
\end{tabular}} & \multicolumn{4}{|c|}{$\mathrm{CaCO}_{3}$ Available nutrients $\left(\mathrm{kg} \mathrm{ha}^{-1}\right)$} & \multirow{2}{*}{$\begin{array}{c}\mathrm{S} \\
\left(\mathrm{mg} \mathrm{kg}^{-1}\right)\end{array}$} \\
\hline & & & & & & & & $(\%)$ & $\mathbf{N}$ & $\mathbf{P}$ & $\mathbf{K}$ & \\
\hline Site 1 (15 years) & 1.34 & 0.71 & 0.67 & & & 0.34 & 6.70 & 7.70 & 221.27 & 20.30 & 416.15 & 10.69 \\
\hline Site 2 ( 8 years) & 1.41 & 0.67 & 0.69 & 12.53 & 8.13 & 0.31 & 6.67 & 7.90 & 198.47 & 17.73 & 407.87 & 10.87 \\
\hline & 1.48 & 0.68 & & & 8.25 & 0.24 & 6.27 & & & 6 & & 10.00 \\
\hline Site 4 (Regular plor & 1.50 & 0.63 & 0.71 & 1.34 & 8.39 & 0.26 & 5.03 & 8.35 & 172.70 & 9.61 & 365.77 & 8.38 \\
\hline Site 5 (12 years) & 1.38 & 0.70 & 0.66 & .73 & 8.00 & 0.32 & 6.90 & 7.78 & 5.17 & 18.35 & 408.57 & 10.14 \\
\hline Site $6(10$ years $)$ & 1.37 & 0.67 & 0.66 & 11.56 & 8.00 & 0.31 & 6.87 & 7.87 & .32 & 17.82 & 409.27 & 10.90 \\
\hline & 1.35 & 0.69 & & & 8.20 & 0.25 & 6.47 & 8.1 & & 14.1 & .33 & 10.00 \\
\hline & 1.48 & 0.66 & 0.70 & 1.88 & 8.26 & 0.25 & 5.80 & 8.2 & & 10. & 367.37 & 9.96 \\
\hline Site 9 ( 1 years $)$ & 1.47 & 0.67 & 0.71 & 10.64 & 8.29 & 0.23 & 6.30 & 8. & & & 391.10 & 9.97 \\
\hline Site 10 (2 years) & 1.48 & 0.67 & 0.71 & 10.81 & 8.28 & 0.25 & 6.03 & 8.23 & 188.39 & 10.04 & 381.53 & 10.02 \\
\hline
\end{tabular}

\section{Results and Discussion \\ Chemical properties of soil \\ Soil pH}

Data pertaining to soil $\mathrm{pH}$ under different treatments are presented in table 4 . The effect of conservation agriculture practices and incorporation of crop residues on soil $\mathrm{pH}$ was non-significant. The $\mathrm{pH}$ influenced by different treatments varied from 7.77 to 8.41 . The lower $\mathrm{pH}$ (7.77) was recorded in $\mathrm{T}_{1}$ where conservation agriculture was followed for last 15 years, followed by 8.02 in $\mathrm{T}_{5}$, where ploughing was not made since last 12 years. The higher soil $\mathrm{pH}$ was also recorded in $\mathrm{T}_{4}$ (8.41) where regular ploughing was followed by farmer. The decrease in soil $\mathrm{pH}$ might be due to long term use of organic manures, crop residues incorporation and long term conservation agriculture practices. The organic manures and crop residues contain large amount of organic nitrogen such as protein and amino acids, which mineralizes to nitrate in soil producing protons during nitrification and hence acidifying the soil. Singh et al. (2014) ${ }^{[24]}$ reported decrease in $\mathrm{pH}$ of soil under farmyard manure, which might be due to the activation of $\mathrm{Al}^{3+}$ and continuous release of basic cation upon its decomposition and gravitational movement of those cations into lower horizons of soil. The similar result also noted by Guled et al. (2002) who has reported that application of organic manures and incorporation of crop residues decreases the $\mathrm{pH}$ of soil. These results are also in conformity with Mandal et al. (2007) ${ }^{[17]}$. The identical result was observed by Rathod et al. (2003) ${ }^{[21]}$ that the $\mathrm{pH}$ of the soil was reduced significantly by application of FYM at 5 tons per ha.

\section{Soil EC}

The data on electrical conductivity influenced by long term conservation agriculture management practices is presented in table 4 . The effect of conservation practices and incorporation of crop residues on electrical conductivity of soil was non- significant. The electrical conductivity as influenced by different treatments varied from 0.24 to $0.35 \mathrm{dSm}^{-1}$. The numerically higher electrical conductivity was observed in $\mathrm{T}_{1}$ $\left(0.35 \mathrm{dSm}^{-1}\right)$ where the farmer have been practicing conservation tillage since last 15 years followed by $\mathrm{T}_{5}(0.32$ $\mathrm{dSm}^{-1}$ ) where no ploughing was practicing since last 12 years and the lower value of electrical conductivity was observed in $\mathrm{T}_{4}\left(0.24 \mathrm{dSm}^{-1}\right)$ where regular ploughing was followed. These results are in accordance with the findings of Guled et al. (2002), who stated that no tillage has more electrical conductivity than conventional tillage system.

\section{Organic carbon}

The results on organic carbon content in soil after harvest of soybean is presented in table 4 . The organic carbon in soil was significantly influenced due to the effect long term no ploughing practice. The organic carbon status under various treatments were assessed and presented in table 7. The organic carbon varied from 5.07 to $7.8 \mathrm{~g} \mathrm{~kg}^{-1}$. Significantly higher value of organic carbon was observed in $T_{1}\left(7.8 \mathrm{~g} \mathrm{~kg}^{-1}\right)$ where conservation agriculture practice was followed since last 15 years followed by $\mathrm{T}_{5}\left(7.67 \mathrm{~g} \mathrm{~kg}^{-1}\right)$ where the same practice was followed for last 12 years. While lower value of organic carbon was registered with $\mathrm{T}_{4}\left(5.07 \mathrm{~g} \mathrm{~kg}^{-1}\right)$ were regular ploughing was practiced each year. The enrichment of soil organic carbon where conservation agriculture management practices was followed since last many years might be due to accumulation of biomass in soil and favorable biological environment. Similar results were noted by Wagh et al. (2016) ${ }^{[27]}$ who stated slightly higher values of organic carbon in conservation tillage as compared to conventional tillage. These results are in accordance with Novak et al. (2009) ${ }^{[19]}$ who reported that conservation tillage increases the soil organic carbon as compared to disc tillage system. Sainju et al. (2009) ${ }^{[22]}$ also noted that no tillage increases organic carbon in soil as compared to tilled plot. Lal and Jacinth 
(2009) ${ }^{[16]}$ reported that organic $\mathrm{C}$ concentration in the $0-5 \mathrm{~cm}$ soil depth were significantly greater under no tillage $(16.3 \mathrm{~g}$ $\left.\mathrm{kg}^{-1}\right)$ compared to conventional tillage $\left(8.8 \mathrm{~g} \mathrm{~kg}^{-1}\right)$. Similar results recorded by Sonune et al. (2012) ${ }^{[25]}$, and stated that, that higher organic carbon under minimum tillage as compared to the conventional tillage in Vertisols.

\section{Calcium carbonate}

The presence of calcium carbonate affects the physical and chemical characteristics of soil. High concentration may not severely restrict water movement but it prevents root penetrations. The calcium carbonate content in the soil as influenced by various treatments is presented in table 4 . The effect of long term conservation agriculture management practices on calcium carbonate content was found to be non- significant. In the present study, the investigation showed calcium carbonate range varied from 7.63 to $8.25 \%$. The lowest value of calcium carbonate was noted in $\mathrm{T}_{1}(7.63 \%)$ where conservation agriculture management practices were followed since last 15 years. Marginal value of calcium carbonate was noted in $\mathrm{T}_{5}(7.71 \%)$ where conservation agriculture management practices were followed since last 12 years and highest value of calcium carbonate was noted in $\mathrm{T}_{4}$ $(8.25 \%)$ where conventional agriculture practices was followed each year. The results are in accordance with the findings of Bellakki and Badanur (1997) ${ }^{[1]}$ and Nehra and Hooda (2002) ${ }^{[18]}$, Katkar (2008) ${ }^{[12]}$ reported slight reduction in calcium carbonate content of Vertisol with organic manure in combination with inorganic fertilizer.

Table 4: Effect of conservation agriculture management practices on soil chemical properties under soybean

\begin{tabular}{|c|c|c|c|c|}
\hline Treatments & pH (1:2.5) & $\mathrm{EC}\left(\mathrm{dS} \mathrm{m^{-1 } )}\right.$ & Organic carbon $\left(\mathrm{g} \mathrm{kg}^{-1}\right)$ & Calcium carbonate $(\%)$ \\
\hline T1: Site 1 (15 years) & 7.77 & 0.35 & 7.80 & 7.63 \\
\hline T2: Site 2 (8 years) & 8.09 & 0.32 & 7.33 & 7.82 \\
\hline T3: Site 3 (4 years) & 8.18 & 0.25 & 6.50 & 8.05 \\
\hline T4: Site 4 (Regular ploughing) & 8.41 & 0.24 & 5.07 & 8.25 \\
\hline T5: Site 5 (12 years) & 8.02 & 0.32 & 7.67 & 7.71 \\
\hline T6: Site 6 (10 years) & 8.05 & 0.29 & 7.47 & 7.83 \\
\hline T7: Site 7 (6 years) & 8.16 & 0.24 & 7.33 & 8.00 \\
\hline T8: Site 8 (1 years) & 8.18 & 0.26 & 5.83 & 8.20 \\
\hline T9: Site 9 (3 years) & 8.26 & 0.23 & 6.53 & 8.12 \\
\hline T10: Site 10 (2 years $)$ & 8.21 & 0.24 & 6.20 & 8.20 \\
\hline $\mathrm{SE}(\mathrm{m}) \pm$ & 0.11 & 0.03 & 0.32 & 0.12 \\
\hline $\mathrm{CD}$ at $5 \%$ & NS & NS & 0.94 & NS \\
\hline
\end{tabular}

\section{Soil Fertility}

\section{Available nitrogen}

Data pertaining to available nitrogen as influenced by different treatments is presented in table 5. The data in respect of available nitrogen as influenced by long term conservation agriculture management practices was found significant. Available nitrogen recorded significantly highest in $T_{1}$ $\left(225.38 \mathrm{~kg} \mathrm{ha}^{-1}\right)$ where conservation agriculture was introduced since last 15 years followed by $\mathrm{T}_{5}\left(209.51 \mathrm{~kg} \mathrm{ha}^{-1}\right)$ where the same practice was followed for last 12 years, and followed by rest of treatments. The lower value of available nitrogen was found in $\mathrm{T}_{4}\left(177.10 \mathrm{~kg} \mathrm{ha}^{-1}\right)$ where regular ploughing was adopted each year. The higher availability of nitrogen was recorded by Khiani and More (1984) ${ }^{[14]}$, due to adoption of harrowing against ploughing in Vertisol due to enhanced decomposition process and mineralization of the nutrients in the soil. Further, the decreasing trend in available nitrogen was noticed as the soil depth increases. Improved nitrogen status after harvest of crop was due to addition of biomass which was stayed large period under conservation tillage. Nitrogen $(\mathrm{N})$ is generally considered to be a major limiting factor (low soil $\mathrm{N}$ status) and is usually applied in sufficient amounts to meet the crop needs. Mineralizationimmobilization processes in soil affect the availability of $\mathrm{N}$ to the crop. High $\mathrm{C} / \mathrm{N}$ ratios and lignin contents cause slow mineralization of soybean crop residues. Irrigated Vertisols of Australia observed lower soil mineral $\mathrm{N}$ content at planting with stubble retained compared to the stubble removed plots. Dick (1983) ${ }^{[5]}$ reported greater amount of nitrogen under notilled surface $(0-30 \mathrm{~cm})$ soil compared to minimum and conventional tillage. Khiani and More (1984) ${ }^{[14]}$ observed through a long term experiment that available nitrogen was higher due to harrowing $\left(85.4 \mathrm{~kg} \mathrm{ha}^{-1}\right)$ than ploughing (81.1 $\mathrm{kg} \mathrm{ha}{ }^{-1}$ ) in Vertisol. The results are in accordance with the findings of Bharambe et al. (1999) ${ }^{[2]}$, Bharambe et al. (2002) [3] and Halemani et al. (2004) reported higher available nitrogen under minimum tillage as compare to conventional tillage.

\section{Available phosphorous}

Data pertaining to available phosphorous as influenced by different treatments are presented in table 5. On perusal of data indicated that available phosphorus in different treatments varied from 10.43 to $23.81 \mathrm{~kg} \mathrm{ha}^{-1}$. The higher value of phosphorus was found in $\mathrm{T}_{1}\left(23.81 \mathrm{~kg} \mathrm{ha}^{-1}\right)$ where the farmer has been following no ploughing practices since last 15 years followed by $\mathrm{T}_{5}\left(21.84 \mathrm{~kg} \mathrm{ha}^{-1}\right)$ where no ploughing was practiced since last 12 years. The lower value of phosphorus was noticed in $\mathrm{T}_{4}\left(10.43 \mathrm{~kg} \mathrm{ha}^{-1}\right)$ where regular ploughing was followed each year. Conservation tillage involves minimum surface tillage, leaving crop residue to accumulate at the soil surface and increase in organic matter ultimately enhance availability of nutrient like phosphorus. Similar observation was also recorded by Dick (1983) ${ }^{[5]}$. Gaikwad and Khupse (1976) ${ }^{[7]}$ observed that available P was higher due to harrowing than ploughing in black soil. Sonune et al., (2012) ${ }^{[25]}$ also observed higher available $\mathrm{P}$ in black cotton soils and minimum tillage compared to conventional tillage. Significant variation was observed in available phosphorus due to the tillage practices. This implies that high organic carbon in soil due to conservation tillage reduces phosphorus fixation due to release of various organic acids as a results of which more phosphorus becomes readily available to plant roots in the soil. Khakural et al. (1992) ${ }^{[13]}$ observed higher available phosphorus due to no-till (16.6 and $41.7 \mathrm{~kg}$ $\mathrm{ha}^{-1}$ ) than a mould board plough (12.2 and $\left.29.5 \mathrm{~kg} \mathrm{ha}^{-1}\right)$, chisel plough ( 8.8 and $37.5 \mathrm{~kg} \mathrm{ha}^{-1}$ ) and ridge till (14.7 and $38.9 \mathrm{~kg} \mathrm{ha}^{-1}$ ) in beadle and worthing soil respectively. 


\section{Available potassium}

Data in respect of available potassium as influenced by different treatments are presented in table 5. In the present investigation available potassium was found profoundly well in respect of different treatments. The available potassium was varied from 367.89 to $419.7 \mathrm{~kg} \mathrm{ha}^{-1}$. The higher value was noticed in $\mathrm{T}_{1}\left(419.7 \mathrm{~kg} \mathrm{ha}^{-1}\right)$ where ploughing was not practiced since last 15 years, followed by $\mathrm{T}_{5}\left(414 \mathrm{~kg} \mathrm{ha}^{-1}\right)$ where same management were practicing since last 12 years. The lower value of potassium was noticed in $\mathrm{T}_{4}(367.89 \mathrm{~kg}$ $\mathrm{ha}^{-1}$ ) where the farmer has been following regular ploughing each year. The higher values might be due to conservation tillage, conserve organic carbon in soil and increase availability nutrient like potassium. Similar observation recorded by Gaikwad and Khuspe (1978) ${ }^{[6]}$ in Vertisol and reported that available potassium was higher with harrowing against ploughing in black soil. Similar results were also observed by Sonune et al. (2012) ${ }^{[25]}$. The increase in available potassium might be due to the fact that available soil moisture would have helped in hastening the decomposition process and mineralization of the nutrients in the soil. The results corroborates with the findings reported by Bharambe et al. (2002) ${ }^{[3]}$ and Halemani et al. (2004) ${ }^{[9,10]}$.

\section{Available sulphur}

Data pertaining to available sulphur as influenced by different treatments are presented in table 5. On close examination of data, it is noticed that, the effect of conservation agriculture management practices on available sulphur was found to be significant. Significantly higher available sulphur was registered in $\mathrm{T}_{1}\left(12.00 \mathrm{~g} \mathrm{~kg}^{-1}\right)$ where conservation agriculture management practices was practiced since last 15 years followed by $\mathrm{T}_{5}\left(11.12 \mathrm{~g} \mathrm{~kg}^{-1}\right)$ where the same management was practiced since last 12 years. The lower value of sulphur was observed in $\mathrm{T}_{4}\left(8.26 \mathrm{~g} \mathrm{~kg}^{-1}\right)$ where regular ploughing was practiced each year. The increased availability of sulphur might be due to enhanced decomposition process and mineralization of the organic manures under conservation tillage. Improvement in available sulphur status under crop residues and green manuring also due to its ameliorative influence on improvement of physical and chemical properties which alters the availability of native sulphur in the soil. The results corroborates with the findings reported by Bharambe et al. (2002) ${ }^{[3]}$ and Halemani et al. $(2004)^{[9,10]}$.

Table 5: Effect of conservation agriculture management practices on available nutrients (NPK and Sulphur) under soybean

\begin{tabular}{|c|c|c|c|c|}
\hline \multirow{2}{*}{ Treatments } & \multicolumn{3}{|c|}{ Available nutrients $\left(\mathrm{kg} \mathrm{ha}^{-1}\right)$} & \multirow{2}{*}{ Available sulphur (mg kg-1) } \\
\hline & $\mathbf{N}$ & $\mathbf{P}$ & K & \\
\hline T1: Site 1 (15 years) & 225.38 & 23.81 & 419.70 & 12.00 \\
\hline T2: Site 2 (8 years) & 204.99 & 20.72 & 412.90 & 11.08 \\
\hline T3: Site 3 (4 years) & 193.50 & 14.82 & 406.83 & 11.10 \\
\hline T4: Site 4 (Regular ploughing) & 177.10 & 10.43 & 367.89 & 8.26 \\
\hline T5: Site 5 (12 years) & 209.51 & 21.84 & 414.00 & 11.12 \\
\hline T6: Site 6 (10 years) & 207.00 & 19.88 & 413.17 & 11.06 \\
\hline T7: Site 7 (6 years) & 200.10 & 17.53 & 410.30 & 10.59 \\
\hline T8: Site 8 (1 years) & 177.08 & 11.20 & 369.47 & 9.90 \\
\hline T9: Site 9 (3 years) & 191.01 & 13.78 & 395.97 & 10.07 \\
\hline T10: Site 10 ( 2 years $)$ & 190.30 & 11.84 & 382.03 & 10.12 \\
\hline $\mathrm{SE}(\mathrm{m}) \pm$ & 7.26 & 2.11 & 10.70 & 0.62 \\
\hline $\mathrm{CD}$ at $5 \%$ & 21.56 & 6.26 & 31.80 & 1.83 \\
\hline
\end{tabular}

\section{Yield of soybean}

The data pertaining to grain and straw yield of soybean presented in table 6 . The yield of soybean as influenced by conservation agriculture management practices was significant. Highest grain yield $\left(24.50 \mathrm{q} \mathrm{ha}^{-1}\right)$ was obtained under $\mathrm{T}_{4}$ where conventional agricultural practices was followed each year followed by $\mathrm{T}_{10}\left(23.67 \mathrm{q} \mathrm{ha}^{-1}\right)$, and $\mathrm{T}_{9}$ (23.37 $\left.\mathrm{q} \mathrm{ha}^{-1}\right)$, where conservation management practices was adopted just one and two years back respectively. Similarly numerically lower grain and straw yield was calculated in $T_{1}$, $\mathrm{T}_{5}, \mathrm{~T}_{6}$, and $\mathrm{T}_{7}$, where conservation agriculture management practices was adopted for last 15, 12, 10 and 6 years, respectively. Generally, increased grain and straw yield to be obtained from conservation agriculture as compare to conventional agriculture as soil fertility achieved through long term conservation agriculture management practices. But the lower trend of crop yield is most, might be due to hardness of black cotton soil, poor hydraulic conductivity and poor soil aeration under conservation agriculture practices. However the yields obtained under conservation agriculture practices are very close to yields obtained in conventional agriculture systems. Singh et al. (2005) ${ }^{[23]}$ carried out a field experiment during three winter seasons at Patna, to find out effect of tillage practices. They concluded that highest soybean grain yield of $36.6 \mathrm{q} \mathrm{ha}^{-1}$ was obtained in zero tillage, followed by conventional tillage (34.1 $\left.\mathrm{q} \mathrm{ha}^{-1}\right)$ and bed planting $\left(31.5 \mathrm{q} \mathrm{ha}^{-1}\right)$.
Table 6: Effect of conservation agriculture management practices on yield of soybean

\begin{tabular}{|c|c|c|}
\hline \multirow{2}{*}{ Treatments } & \multicolumn{2}{|c|}{ Soybean yield (q ha' $\left.\mathbf{~ h a}^{\mathbf{1}}\right)$} \\
\cline { 2 - 3 } & Grain yield & Straw yield \\
\hline T1: Site 1 (15 years) & 22.90 & 25.37 \\
\hline T2: Site 2 (8 years) & 21.00 & 24.17 \\
\hline T3: Site 3 (4 years) & 23.23 & 26.37 \\
\hline T4: Site 4 (Regular ploughing) & 24.50 & 28.20 \\
\hline T5: Site 5 (12 years) & 22.50 & 24.40 \\
\hline T6: Site 6 (10 years) & 22.00 & 26.10 \\
\hline T7: Site 7 (6 years) & 21.00 & 23.97 \\
\hline T8: Site 8 (1 years) & 23.03 & 26.80 \\
\hline T9: Site 9 (3 years) & 23.37 & 26.27 \\
\hline T10: Site 10 (2 years) & 23.67 & 27.17 \\
\hline SE (m) \pm & 0.70 & 0.82 \\
\hline CD at 5\% & 2.09 & 2.43 \\
\hline CV & 5.36 & 5.47 \\
\hline
\end{tabular}

\section{Conclusion}

Based on the investigation, the residual fertility of soil in respect of available N,P,K and sulphur were enhanced under conservation agricultural practices. Significantly increasing trend of soil fertility status investigated in $\mathrm{T}_{1}$ compare to other treatments, while, the highest grain and straw yield of soybean was registered with regular ploughing.

Hence, it is concluded that the consistent adoption of 
conservation agricultural practices supported well to enhance the soil health parameters and also noted significant change in yield of soybean. Therefore, adoption of conservation agriculture practices is advisable for long term sustainability of soil in rainfed agricultural system.

\section{Acknowledgement}

No matter how impersonal a scientific dissertation may seem, it involves lot of elements. At this inexplicable moment, words are not in lexicon to express my sincere sense of gratitude, but with full honour and ecstasy of delight I express my acknowledgment here.

I feel immense pleasure to acknowledge my profound, sincere, humble and deepest sense of gratitude and indebtedness for valuable guidance of my guide Dr. N. M. Konde, Assistant Professor (In-charge Education) Department of SSAC, Dr. PDKV Akola.

It is my privilege to record my sincere and devoted thanks to members of my advisory committee Dr. V. K. Kharche Director of Research, Dr. PDKV Akola, Dr. S. M. Bhoyar Head, Department of Soil Science and Agricultural Chemistry, Dr. PDKV Akola, Dr. N. W. Raut, Assistant Professor, Department of Agronomy, Dr. PDKV Akola, for their keen interest and valuable suggestions from time to time in persuade of present investigation.

I am very much indebted to Dr. S. M. Bhoyar, Head, Department of Soil Science and Agricultural Chemistry and Dr. Y. B. Taide, Associate Dean, PGI, Dr. PDKV, Akola for providing necessary facilities during the course of investigation to complete this research work.

My sincere and deepest thanks to, Dr. V. D. Guldekar, Dr. R. N. Katkar, Dr. S. D. Jadhao, Dr. P. W. Deshmukh, Dr. S. S. Hadole, Dr. D. V. Mali, Dr. B. A. Sonune, Dr. D. S. Kankal, Shri. A. B. Aage, Shri. P. A. Sarap for their valuable guidance and help.

I am thankful to all the staff members of Department of Soil Science and Agricultural Chemistry, Dr. PDKV, Akola for their generous co-operation.

Last but not the least, I would like to thank each and everyone who helped me directly and indirectly for completion of my research work.

\section{References}

1. Bellakki MA, Badanur VP. Long term effect of integrated nutrient management on properties of Vertisol under dryland agriculture. J Indian Soc. Soil Sci 1997;45(3):438442.

2. Bharambe PR, Patil MA, Oza SR, Shelke DK. Effect of crop residue incorporation and irrigation on sunflower yield and soil productivity under sorghum-sunflower cropping system. J. Indian Soc. Soil Sci 1999;47(1):169171.

3. Bharambe PR, Shelke DK, Oza SR, Vaishnava VG. Effect of irrigation levels on spatial moisture distribution, soilplant-water relations and water use efficiency of cotton under drip irrigation. J Indian Soc. Soil. Sci. 2002;50(3):303-305.

4. Chesin L, Yien $\mathrm{CH}$. turbidimetric determition of available sulphur. Soil. Sci. Soc. of America. Precidings. 1950;950(28):149-151.

5. Dick WA. Organic carbon, nitrogen and phosphorus and $\mathrm{pH}$ in soil profiles as affected by tillage intensity. Soil. Soc. Am. J 1983;47:102-107.

6. Gaikwad, CB, Khuspe VS. Impact of integrated nutrient management practices on soil properties. Indian Farmers Digest 1978;27:9-11.
7. Gaikwad CB, Khuspe VS. Long term effect of tillage and manuring on some physical and chemical properties in black soil under rainfed cropping. J. Maharashtra Agric. Univ 1976;1(2-6):145-147.

8. Gomez KA, Gomez AA. Statistical procedure for agriculture research, $2^{\text {nd }}$ Edition John Wiley and Sons Publication, Newyork 1984.

9. Halemani HL, Hallikeri SS, Nandagavi RA, Nooli SS, Mohan Kumar G. Influence of organics, inorganics and their combinations on soil properties and crop productivity in cotton based cropping system. In: International symposium on "Strategies for sustainable cotton production - A global vision" 2. Crop Production, 23-25, Nov. 2004, UAS, Dharwad 2004, 174-180.

10. Halemani HL, Hallikeri SS, Nooli SS, Nandagavi RA, Kumar HS. Effect of organics on cotton productivity and physico-chemical properties of soil. In: International symposium on "Strategies for sustainable cotton production - A global vision" 2. Crop Production, 23-25, Nov. 2004, UAS, Dharwad 2004, 123-129.

11. Jackson ML. Soil Chemical Analysis. Prentice Hall Publication Pvt. Ltd., New Delhi, India 1973.

12. Katkar RN. Effect of crop residue management and moisture regimes on soil properties, plant growth, seed cotton yield, water use efficiency and fibre quality (Ph.D thesis unpublished) Dr. Panjabrao Deshmukh Krishi Vidyapeeth Akola 2008.

13. Khakural BR, Lemme GD, Schumacher TE, lindstrom MJ. Effect of tillage system and landscape on soil. Soil and Tillage Res 1992;25:43-52.

14. Khiani KN, More DA. Long term effect of tillage operation and farm yard manure application on soil properties and crop yield in Vertisol. J. Indian Soc. Soil Sci 1984;32:392-393.

15. Knudsen D, Peterson GA. In: Methods of Soil Analysis, Part II, Chemical and Microbiological Methods by Page, A.L., R.H. Miller and D.R. Keeney (eds.), Agronomy Monograph No. 9 ( $2^{\text {nd }}$ edition) American Society of Agronomy and Soil Science Society of America, Madison, Wisconsin, USA 1982, 228-231.

16. Lal R, Jacinthe PA. Tillage effect on carbon sequestration and microbial biomass in reclaimed farm land soils of southwestern Indian. Soil. Soc. Am. J 2009;73:605-613.

17. Mandal A, Patra AK, Singh D, Swarup A, Masto RE Effect of long term application of manure and fertilizer on biological and biochemical activities in soil during crop development stages. Bioresour. Technol 2007;98(18):3585-3592.

18. Nehra AS, Hooda IS. Influence of integrated use of organic manures and inorganic fertilizers on wheat yield and soil properties. Res. on Crops 2002;3(1):11-16.

19. Novak JM, Frederick JR, Bauer PJ, Watts DW. Rebuilding organic carbon content in coastal plain soils using conservation tillage systems. Soil Sci. Soc. Am. J 2009;73:622-629.

20. Piper CS. Soil and Plant Analysis, Hans. Pub. Bombay. Asian Ed 1966, 368-374.

21. Rathod VE, Sagare BN, Ravankar HN, Sarap PA, Hadole SS. Efficacy of amendments for improvement in soil properties and yield of cotton grown in sodic Vertisols of Vidarbha using alkali water. Journal of Soils and Crops 2003;13(1):176-178.

22. Sainju UM, Jabro JD, Tonthat TC. Carbon and nitrogen fraction in dryland soil aggregates affected by long-term 
tillage and cropping sequence. Soil. Sci. Soc. Am. J 2009;73:1488-1495.

23. Singh SS, Prasad LK, Upadhyaya A. "Root growth, yield and economics of wheat (Triticum aestivum) as affected by irrigation and tillage practices in south bihar". Indian Journal of Agronomy 2005;51(2):131-134.

24. Singh Muneshwar, Shri Ram, Wanjari RH, Pankaj Sharma. Balance and forms of potassium under rice-wheat system in a 40-year-old long-term experiment on Mollisols of Pantnagar. J. Indian Soc. Soil Sci 2014;62(1):38-44.

25. Sonune BA, Gabhane VV, Rewatkar SS, Sawangikar MS. Productivity of rainfed cotton and soil health as influenced by tillage and integrated nutrient management in Vertisol under semi-arid agro-ecosystem of Maharashtra. Indian J. Dryland Agric. Res and Dev 2012;27(1):10-17.

26. Subbiah BV, Asija GV. A rapid procedure for determination of available nitrogen in soils. Current Sci 1956;25:256-260.

27. Wagh NS, Katkar RN, Kharche VK. Effect of tillage and nutrient management on soil properties, growth and seed cotton yield. National Academy of Agricultural Science (NAAS) 2016;34(6):1423-1434.

28. Watanabe, Olsen. Test of an ascorbic acid method for determining phosphorus in water and $\mathrm{NaHCO}_{3}$ extract from soil. Soil. Sci. Soc. Am. J 1965;29(6):1965. 